\title{
APLIKASI EKSTRAK BIJI PINANG (Areca Catechu L) SEBAGAI ZAT ANTIBAKTERI PADA KAIN KAPAS
}

\author{
APPLICATION OF PINANG SEED EXTRACTS (Areca Catechu L) \\ AS AN ANTIBACTERIAL AGENT IN COTTON FABRICS
}

\author{
Srie Gustiani, Wulan Septiani, Cica Kasipah \\ Balai Besar Tekstil, Jalan Jenderal Ahmad Yani No. 390 Bandung \\ E-mail: texirdti@bdg.centrin.net.id
}

Tanggal diterima: 13 Nopember 2018, direvisi: 31 Desember 2019, disetujui terbit: 31 Desember 2019

\begin{abstract}
ABSTRAK
Kepedulian masyarakat mengenai kesehatan semakin berkembang, dibuktikan dengan banyaknya penelitian mengenai antibakteri khususnya pada material tekstil. Penambahan finishing agent antibakteri pada kain kapas akan mencegah tumbuhnya bakteri yang akan menimbulkan bau, gatal, dll pada kulit yang bersentuhan langsung dengan kain. Pada penelitian ini dilakukan penambahan zat aktif antibakteri dari ekstrak biji pinang pada kain kapas. Kain kapas antibakteri ini dibuat dari kain kapas yang dilapisi larutan ekstrak biji pinang (variasi konsentrasi $1 \mathrm{~g} / \mathrm{l}, 5 \mathrm{~g} / \mathrm{l}$ dan $10 \mathrm{~g} / \mathrm{l}$ ) dan binding agent (variasi jenis agent polivinil alkohol, poliuretan dan binder 722). Proses pelapisan dilakukan menggunakan metoda rendam peras-pemanasawetan (pad-dry-cure) dan hasil proses dibandingkan dengan kain kapas blanko. Karakterisasi pada kain hasil proses meliputi pengamatan morfologi (SEM), analisa gugus fungsi (FTIR) dan uji aktivitas antibakteri. Hasil penelitian menunjukan bahwa pinang dapat digunakan sebagai antibakteri pada kain kapas, berdasarkan hasil uji antibakteri. Binder 722 merupakan crosslinking agent yang paling baik untuk mengikat pinang pada kain, hal ini dapat dilihat dari efektivitas dan durabilitasnya dalam mencegah pertumbuhan bakteri. Setelah 9 kali pencucian rumah tangga, efisiensi pencegahan pertumbuhan bakteri E. coli hanya menurun dari $99,5 \%$ menjadi $97,4 \%$ dan S. aureus menurun dari $95,1 \%$ menjadi $92,2 \%$. Dari hasil SEM kain tanpa pinang terlihat tidak ada partikel yang menempel. Semakin besar konsentrasi ekstrak pinang, maka makin banyak pinang yang menempel pada kain. Dari hasil uji FTIR dapat dilihat adanya puncak serapan pada pangan gelombang 1579 dan $1502 \mathrm{~cm}-1$, yang menunjukkan adanya pinang yang menempel pada kain yang telah diproses.
\end{abstract}

Kata Kunci: Tekstil, antibakteri, kain kapas, pinang

\begin{abstract}
Public awareness about health is growing, as evidenced by the abundance of research on antibacterials, especially in textile materials. The addition of an antibacterial finishing agent to the cotton fabric will prevent the growth of bacteria that will cause odor, itching, etc. on the skin that comes into direct contact with the fabric. In this research, the addition of antibacterial active substances from betel nut extract on cotton fabric. This antibacterial cotton cloth is made from cotton fabric coated with areca nut extract solution (concentration variation of $1 \mathrm{~g} / \mathrm{l}, 5 \mathrm{~g}$ $/ l$ and $10 \mathrm{~g} / \mathrm{l}$ ) and binding agent (variations in the type of polyvinyl alcohol, polyurethane and binder 722 agents). The coating process is carried out using a pad-dry-cure soak and the results are compared with a blank cotton fabric. Characterization of the resulting fabric includes morphological observation (SEM), functional group analysis (FTIR) and antibacterial activity test. The results showed that areca nut can be used as an antibacterial on cotton fabrics, based on antibacterial test results. Binder 722 is the best crosslinking agent for binding areca nut to a cloth. This can be seen from its effectiveness and durability in preventing bacterial growth. After 9 times household washing, the efficiency of preventing the growth of E. coli bacteria only decreased from $99.5 \%$ to $97.4 \%$ and S. aureus decreased from $95.1 \%$ to $92.2 \%$. From the SEM results of the cloth without areca nuts, there are no particles attached. The greater the concentration of areca extract, the more areca nuts attach to the fabric. From the results of the FTIR test it can be seen that there are absorption peaks in the wave food of 1579 and $1502 \mathrm{~cm}-1$, which indicate the presence of areca sticks attached to the processed fabric.
\end{abstract}

Keywords: Textile, antibacteria, cotton fabrics, areca nut 


\section{PENDAHULUAN}

Saat ini dengan berkembangnya produksi tekstil fungsional, hal yang mendapat perhatian adalah tekstil fungsional di bidang kesehatan salah satunya adalah antibakteri pada kain kapas. Kapas merupakan bahan yang memiliki kekuatan, daya tahan (durabilitas), dan daya serap yang unik namun disukai orang. Kain kapas bersifat menghangatkan di kala dingin dan menyejukkan di kala panas (menyerap keringat). Bahan kapas ini banyak digunakan untuk dijadikan pakaian seperti kemeja, pakaian bayi, dan banyak lagi. Karena itu dengan aplikasi antimikroba dalam kain kapas dapat meningkatkan kenyamanan bagi penggunanya. Menurut Ganiswarna (1999), antimikroba $(\mathrm{L}$, anti = lawan, mikro = kecil $)$ adalah zat-zat kimia yang dihasilkan oleh fungi dan bakteri, yang memiliki fungsi khasiat kuman, sedangkan toksisitasnya bagi manusia relatif kecil. Turunan zat tersebut yang dibuat secara semisintetik termasuk kelompok ini, begitu pula senyawa sintesis dengan khasiat antibakteri lazimnya disebut antibiotika ${ }^{1}$. Antibiotik ialah zat yang dihasilkan oleh suatu mikroba, terutama fungi, yang dapat menghambat atau dapat membasmi mikroba jenis lain. Banyak antibiotik dewasa ini dibuat secara semisintetik atau sintetik penuh. Namun dalam praktek sehari-hari antimikroba sintetik yang tidak diturunkan dari produk mikroba (misalnya sulfonamida dan kuinolon) juga sering digolongkan sebagai bahan antibiotik ${ }^{2}$. Mengenal pentingnya bahan tanaman sebagai bahan antibakteri, banyak penelitian yang dilakukan di bidang produk tekstil bioaktif sebagai perlindungan bagi pengguna produk dari mikroba yang umumnya menyebabkan infeksi. Bahan antimikroba alami tidak bersifat racun dan tidak menyebabkan alergi ${ }^{3}$. Dalam beberapa tahun terakhir, resistensi obat pada manusia, hewan dan tumbuhan patogen akibat penyalahgunaan antibiotik untuk pengobatan penyakit menular telah berkembang. ${ }^{5}$ Dalam makanan yang mengandung patogen, resistensi antimikroba meningkat selama beberapa dekade terakhir ${ }^{6,7}$. Situasi yang mengkhawatirkan ini menyebabkan ahli mikrobiologi mencari senyawa antimikroba baru dari berbagai sumber, termasuk tanaman obat ${ }^{8}$. Tanaman obat ini digunakan dalam pengobatan tradisional sebagai obat karminatif, stimulan, antiseptik, antijamur, dan antibakteri ${ }^{9}$.

Menurut Dwidjoseputro (2003) antibiotika yang ideal sebagai obat harus memenuhi syaratsyarat berikut:

1. Mempunyai kemampuan untuk mematikan atau menghambat pertumbuhan mikroorganisme yang luas (broad spectrum antibiotic).

2. Tidak menimbulkan terjadinya resistensi dari mikroorganisme pathogen.

3. Tidak menimbulkan pengaruh samping (side effect) yang buruk pada host seperti reaksi alergi, kerusakan syaraf, iritasi lambung, dan sebagainya.

4. Tidak mengganggu keseimbangan flora yang normal dari host seperti flora usus atau flora kulit $^{10}$.

Dalam pemilihan bahan untuk antimikroba, selain persyaratan diatas juga perlu diperhatikan keberlimpahan bahan di Indonesia. IARC (2014) menyebutkan di Taiwan dan Asia Tenggara, beberapa jenis tanaman seperti daun sirih, pinang, limau dan tembakau telah diklasifikasikan sebagai tanaman obat bagi manusia.

Pinang (Areca Catechu L), merupakan salah satu tanaman obat yang banyak dimanfaatkan untuk tujuan komersial karena memiliki nilai ekonomis yang tinggi dalam berbagai bidang, hanya belum banyak dikelola ${ }^{12}$. Tanaman ini dikatakan sebagai tanaman serbaguna karena mulai dari daun, batang, serabut, dan biji dapat dimanfaatkan. Daun tanaman tersebut, banyak mengandung minyak atsiri, biji buahnya banyak mengandung tannin dan alkaloid sebagai obat dan penyamak pada industri kulit. Serabut buahnya digunakan sebagai obat gangguan pencernaan, sembelit, aderma dan beri-beri. Batangnya dapat di gunakan sebagai bahan bangunan, jembatan, saluran air dan sebagainya. Biji pinang banyak mengandung beberapa komponen senyawa kimia yang sangat penting yaitu: Tannin, alkaloid, lemak, minyak atsiri, air dan sedikit gula. Tannin adalah salah satu senyawa yang terkandung dalam buah pinang yang kadarnya cukup tinggi. Tannin diperoleh dengan cara ekstraksi dengan pelarut air dan etanol karena tannin dapat larut dalam pelarut tersebut. Tannin merupakan senyawa yang sangat penting penggunaannya dalam bidang kesehatan dan bidang industri ${ }^{12}$.

Berdasarkan strukturnya, tannin dibedakan menjadi dua kelas, yaitu tannin terkondensasi dan tannin terhidrolisis. Senyawa yang banyak terkandung dalam biji pinang termasuk dalam tannin terkondensasi yang biasannya terdiri dari polimer flavonoid yang merupakan senyawa fenol. tannin jenis ini banyak ditemukan di tanaman pakupakuan. Nama lain dari tannin ini adalah Proantosianidin. ${ }^{13}$

Proantosianidin adalah suatu tannin terkondensasi yang termasuk dalam golongan flavonoid. ${ }^{14}$ Proantosianidin mempunyai efek antibakteri, antivirus, antikarsinogenik, antiinflamasi, anti-alergi, dan vasodilatasi. ${ }^{15}$

Ketertarikan terhadap teknologi pakaian mengalami peningkatan di hampir seluruh dunia, termasuk permintaan untuk menghasilkan produk yang memiliki fungsi tahan kusut dan tahan air.. Christine Martz (2011), membuat celana denim yang dilapisi panty antibakteri. Orhan dkk., 2007 melakukan penelitian mengenai penggunaan triclosan sebagai finishing agent pada proses tekstil. 
Pada tahun 2015, Kemi Swedish Chemicals Agency melakukan penelitian untuk membuktikan pengaruh zat antibakteri pada tekstil. Dari beberapa penelitian yang dilakukan oleh peneliti terdahulu, belum dilakukan penelitian mengenai pakaian dalam antibakteri. Penelitian ini dilakukan untuk mengetahui efektivitas biji pinang sebagai antibakteri pada kain kapas.

\section{METODOLOGI}

\section{Bahan dan peralatan penelitian}

Bahan yang digunakan dalam penelitian ini antara lain: kain kapas gramasi 46,3 (gr/ $\left./ \mathrm{cm}^{2}\right)$, serbuk biji pinang, nutrien agar, bakteri gram negatif Escherichia coli, bakteri gram positif Staphylococcus aureusaureus, polivinil alkohol, poliuretan, binder 722 , buffer fosfat, dan akuades.

Peralatan yang digunakan antara lain: alatalat gelas, blender, saringan, inkubator, freeze dryer, oven, mesin padding dan mesin curing.

\section{Ekstraksi serbuk pinang}

Serbuk pinang yang didapat dari pasaran diekstraksi dengan variasi berat pinang yaitu $1 \mathrm{~g} / \mathrm{L}$, $5 \mathrm{~g} / \mathrm{L}$, dan $10 \mathrm{~g} / \mathrm{L}$ dalam 1 liter air, masing-masing dalam gelas piala 1 liter yang selanjutnya dididihkan hingga tersisa volume larutan sebanyak $500 \mathrm{~mL}$.

\section{Proses Pad Dry Cure}

Pakaian dalam dari bahan kapas yang dibeli di pasaran direndam dalam larutan ekstrak pinang dengan variasi konsentrasi $1 \mathrm{~g} / \mathrm{L}, 5 \mathrm{~g} / \mathrm{L}$,dan $10 \mathrm{~g} / \mathrm{L}$. Pada masing-masing konsentrasi ekstrak pinang juga dilakukan variasi binding agent, yaitu PVA, binder 722, dan poliuretan. Proses dilanjutkan dengan rendam peras (padding) pada WPU $80 \%$ dan pemanasawetan (curing) pada temperatur $110^{\circ} \mathrm{C}$ selama 1 menit. Selanjutnya sampel dikeringkan pada temperatur kamar.

\section{Uji kuantitatif antibakteri bahan tekstil}

Uji kuantitatif antibakteri dilakukan terhadap 2 jenis bakteri, yaitu $E$. coli dan $S$. aureus. Pengujian antibakteri pada material tekstil dilakukan merujuk kepada AATCC 100 - 2004. Inokulum bakteri dikulturkan selama 24 jam sambil dikocok pada shaker hingga dihasilkan larutan inokulum yang mengandung sekitar $1-2.10^{5}$ mikroorganisme $/ \mathrm{mL}$. Sebelum diteteskan pada kain, inokulum dibiarkan 15 menit tanpa dikocok. Dua contoh uji (yang telah disterilkan menggunakan autoclave selama 15 menit) diletakkan pada cawan petri kemudian ditetesi sekitar $1 \mathrm{~mL}$ inokulum hingga terbasahi sempurna. Kain segera dimasukkan dalam bejana tertutup dan dibiarkan selama 0 jam (blanko) dan 24 jam (sampel). Untuk pengujian 0 jam, bejana yang berisi kain segera ditambahkan $100 \mathrm{~mL}$ akuades steril kemudian dikocok dengan kuat selama 1 menit. Untuk pengujian 24 jam, setelah 24 jam ditambahkan 100 $\mathrm{mL}$ akuades steril kemudian dikocok dengan kuat selama 1 menit. Dari larutan yang dihasilkan, masing-masing dibuat pengenceran 100 kali. Larutan agar disiapkan dengan melarutkan 23 gram nutrien agar ke dalam 1 liter larutan bufer fosfat $\mathrm{pH}$ 7. Pada cawan petri dituangkan larutan nutrien agar sebanyak $15 \mathrm{~mL}$, kemudian setelah dingin dibungkus dengan kertas lalu disterilkan di dalam autoclave selama 15 menit. Sebanyak $0,1 \mathrm{~mL}$ larutan inokulum yang telah diencerkan dipipet masing-masing ke dalam dua buah cawan petri berisi nutrien agar, kemudian segera tutup cawan petri lalu diinkubasi selama 48 jam. Setelah 48 jam, jumlah koloni mikroorganisme dihitung dengan mengalikan faktor pengenceran yang dilakukan. Hasil penghitungan koloni bakteri dinyatakan dalam Colony Forming Unit, CFU/mL.

$$
\% \mathrm{R}(\% \text { reduksi })=\frac{\text { Blanko }- \text { Sampel }}{\text { Blanko }} \times 100 \%
$$

\section{HASIL DAN PEMBAHASAN \\ Antibakteri pada kain}

Ketahanan senyawa flavonoid dalam hal antibakteri telah ditunjukkan dalam banyak literatur. Hernandez, dkk dalam penelitiannya yang berjudul Antimicrobial activity of flavonoids in medicinal plants from Tafi' del Valle (Tucuma'n, Argentina) menyebutkan bahwa empat dari lima spesies tumbuhan yang dipelajarinya memiliki aktivitas antimikroba dengan kadar yang berbeda dan dapat menghambat hampir semua mikroorganisme yang digunakan dalam penelitiannya. Selain itu, hasil penelitian Rauha, dkk juga menunjukkan adanya aktivitas penghambatan dari senyawa flavonoid terhadap bakteri walaupun terdapat kemungkinan adanya ekstrak senyawa lain yang bersifat antibakteri.

Pada penelitian ini digunakan serbuk pinang sebagai antibakteri. Pinang diekstrak dengan menggunakan air. Uji antibakteri dilakukan pada kain kapas yang tidak diproses dengan pinang, serta kain yang diproses dengan pinang pada konsentrasi 1,5 dan $10 \mathrm{~g} / \mathrm{L}$. Pada perlakuan ini, tidak dilakukan pencucian dan penambahan binding agent. Tabel 1 menunjukkan hasil uji aktivitas antibakteri dari pinang pada kain kapas. Kemampuan pinang sebagai antibakteri menunjukkan hasil yang baik, yaitu mampu menghambat pertumbuhan bakteri selama 48 jam sebesar $98,4 \%$ terhadap bakteri $E$. coli dan $98,9 \%$ untuk bakteri S. aerus masingmasing pada konsentrasi pinang $10 \mathrm{~g} / \mathrm{L}$. Dari hasil uji tersebut, pinang sangat baik untuk digunakan sebagai antibakteri. Pinang dapat menghambat pertumbuhan bakteri gram negatif dan gram positif dengan sangat baik, maka dapat digunakan sebagai 
antibakteri pakaian dalam untuk pencegahan keputihan. Adanya aktivitas antibakteri terhadap Staphylococcus aureus, Staphylococcus epidermidis, Bacillus subtilis, and Escherichia coli ini ditunjukkan karena adanya kandungan senyawa kuersetin dan naringenin. ${ }^{17}$

Pada penelitian ini dilakukan pula proses pemberian antibakteri pada pakaian dalam dengan penambahan binding agent, diantaranya polivinil alkohol (PVA), poliuretan dan binder 722. Tabel 2 menunjukkan hasil uji antibakteri kain kapas yang diproses dengan ekstrak pinang menggunakan binding agent. Hasil uji tersebut menyatakan bahwa penggunaan binder dapat membuat pinang tetap menempel pada kain dan masih berfungsi dengan baik sebagai antibakteri, walaupun telah mengalami proses pencucian rumah tangga sebanyak 9 kali. Untuk kain yang telah diproses dengan ekstrakpinang, binder 722 merupakan binding agent yang paling baik dalam mengikat pinang agar menempel pada kain. Setelah pencucian rumah tangga sebanyak 9 kali, kain kapas tersebut tidak mengalami penurunan efisiensi dalam pencegahan pertumbuhan bakteri. Efisiensi pencegahan pertumbuhan pada bakteri $E$. coli hanya menurun dari $99,5 \%$ menjadi $97,4 \%$ dan $S$. aureus menurun dari $95,1 \%$ menjadi $92,2 \%$.<smiles>O=c1c(O)cc(-c2ccc(O)c(O)c2)cc2cc(O)cc(O)c12</smiles>

(a)<smiles>O=C1CC(c2ccc(O)cc2)Oc2cc(O)cc(O)c21</smiles>

(b)
Gambar 1. Kuersetin (a), Naringenin (b)

Tabel 1. Hasil Uji Antibakteri Kain Kapas yang Diproses dengan Ekstrak Biji Pinang

\begin{tabular}{|c|c|c|c|c|c|c|}
\hline \multirow{2}{*}{$\begin{array}{l}\text { Variasi Konsentrasi } \\
\text { ekstrak pinang } \\
\text { (g/L) }\end{array}$} & \multicolumn{3}{|c|}{ Bakteri Escherichia coli } & \multicolumn{3}{|c|}{ Bakteri Staphylococcus aureus } \\
\hline & $\begin{array}{c}\text { Inkubasi } \\
\text { 0 jam }\end{array}$ & $\begin{array}{l}\text { Inkubasi } \\
24 \text { jam }\end{array}$ & $\% \mathbf{R}$ & $\begin{array}{l}\text { Inkubasi } \\
0 \text { jam }\end{array}$ & $\begin{array}{l}\text { Inkubasi } \\
24 \text { jam }\end{array}$ & $\% \mathbf{R}$ \\
\hline Kain blanko & 3.000 .000 & 3.000 .000 & 0 & 5.000 .000 & 5.000 .000 & 0 \\
\hline 1 & 103.000 .000 & 3.000 .000 & 97,1 & 148.000 .000 & 3.000 .000 & 97,9 \\
\hline 5 & 172.000 .000 & 3.000 .000 & 98,3 & 241.000 .000 & 3.000 .000 & 98,8 \\
\hline 10 & 192.000 .000 & 3.000 .000 & 98,4 & 176.000 .000 & 2.000 .000 & 98,9 \\
\hline
\end{tabular}

Tabel 2. Hasil Uji Antibakteri Kain Kapas yang Diproses dengan Ekstrak Biji Pinang dengan Variasi Binder

\begin{tabular}{|c|c|c|c|c|c|c|c|}
\hline \multirow[b]{2}{*}{ Jenis Binder } & \multirow{2}{*}{$\begin{array}{l}\text { Pencucian rumah } \\
\left.\text { tangga }{ }^{*}\right)\end{array}$} & \multicolumn{3}{|c|}{ Bakteri Escherichia coli } & \multicolumn{3}{|c|}{ Bakteri Staphylococcus aureus } \\
\hline & & $\begin{array}{c}\text { Inkubasi } \\
0 \text { jam }\end{array}$ & $\begin{array}{l}\text { Inkubasi } \\
24 \text { jam }\end{array}$ & $\% \mathbf{R}$ & $\begin{array}{c}\text { Inkubasi } \\
0 \text { jam }\end{array}$ & $\begin{array}{l}\text { Inkubasi } \\
24 \text { jam }\end{array}$ & $\% R$ \\
\hline \multicolumn{2}{|c|}{ Kain blanko } & 3.760 .000 & 3.760 .000 & 0 & 580.000 & 700.000 & $-20,7$ \\
\hline \multirow{2}{*}{ Poly Vinil Alkohol } & Sebelum pencucian & 3.520 .000 & 10.000 & 99,7 & 2.100 .000 & 350.000 & 92,9 \\
\hline & $9 \times$ cuci & 5.280 .000 & 60.000 & 98,9 & 1.160 .000 & 110.000 & 90,5 \\
\hline \multirow{2}{*}{ Binder 722} & Sebelum pencucian & 4.240 .000 & 20.000 & 99,5 & 6.000 .000 & 280.000 & 95,1 \\
\hline & $9 \times$ cuci & 4.64 .000 & 120.000 & 97,4 & 4.880 .000 & 380.000 & 92,2 \\
\hline \multirow{2}{*}{ Poly uretan } & Sebelum pencucian & 5.200 .000 & 0 & 100 & 3.200 .000 & 530.000 & 83,4 \\
\hline & $9 \times$ cuci & 5.000 .000 & 50.000 & 99,1 & 1.760 .000 & 470.000 & 73,3 \\
\hline
\end{tabular}

*) $1 \mathrm{X}$ pencucian di laboratorium $=3 \mathrm{X}$ pencucian rumah tangga (SNI-ISO 105-C06: 2010) 
Hasil ini ditunjukkan dengan tidak adanya penurunan efisiensi secara signifikan pada kain yang telah diproses pinang dengan ditambahkan binder. Untuk kain yang diproses dengan penambahan binder, hasil menunjukkan bahwa binder 722 merupakan binder yang paling baik karena setelah dicuci sebanyak 9 kali tidak terjadi penurunan sifat antibakteri dalam mencegah pertumbuhan bakteri $E$. coli dari $99,, 5 \%$ menjadi $97,4 \%$ dan S. aureus dari 95,1\% menjadi $92,2 \%$.

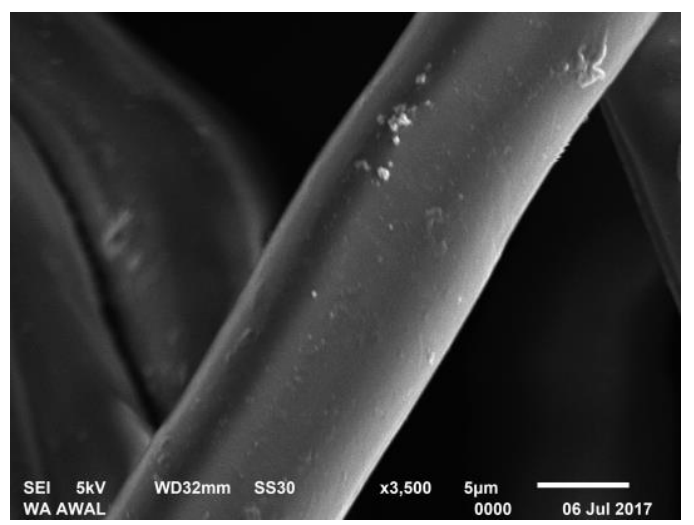

(a)

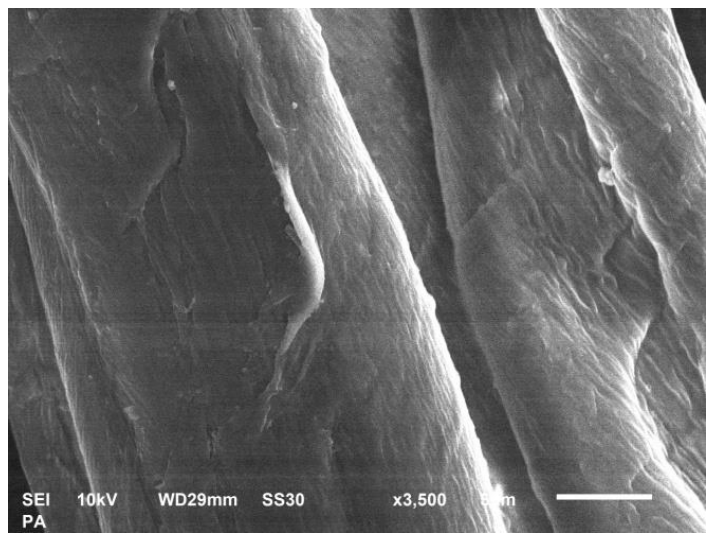

(c)

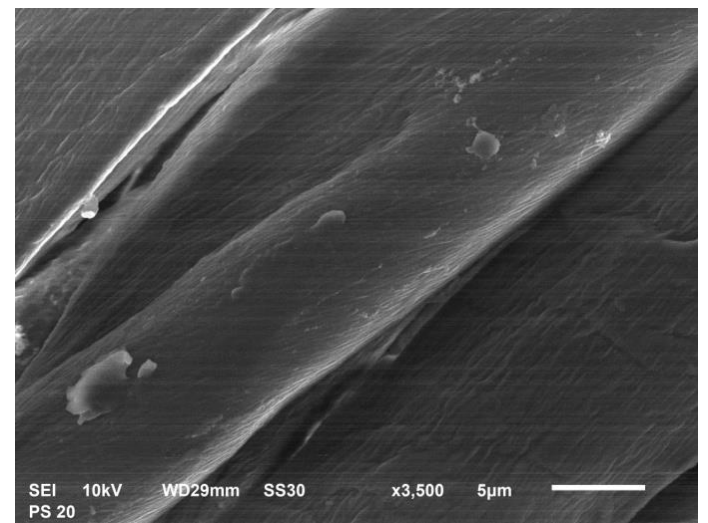

(b)

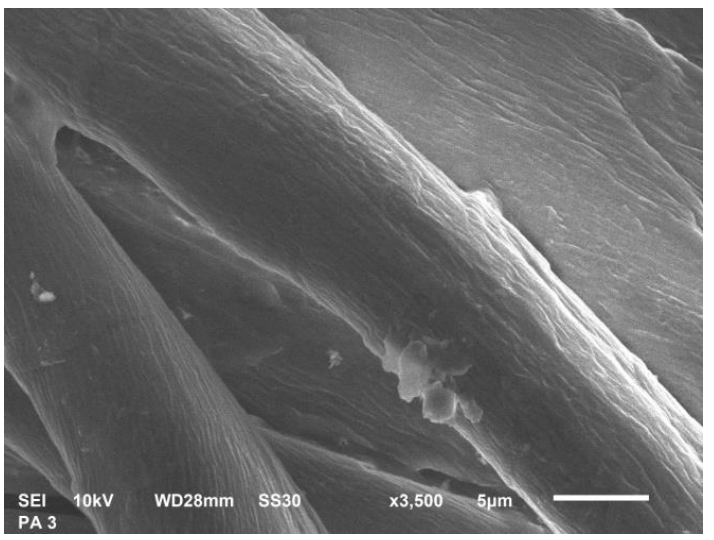

(d)

Gambar 2. Citra SEM kain kapas (a) tanpa pinang; (b) diproses dengan pinang 20 g/L; (c) kain kapas diproses dengan pinang + Binder 722; (d) kain kapas diproses dengan pinang + Binder 722 setelah dicuci

\section{Citra SEM}

Gambar 2 menunjukkan morfologi serat kain yang dilapisi dan tidak dilapisi oleh pinang. Pada Gambar 2 a, dapat terlihat penampang serat yang tidak dilapisi oleh partikel pinang dimana permukaan serat terlihat bersih. Pada gambar $2 \mathrm{~b}, \mathrm{c}$, dan d terlihat penampang serat dilapisi partikel halus. Semakin besar konsentrasi pinang, maka semakin banyak pula terlihat partikel berupa bulubulu halus menempel pada penampang serat. Morfologi kain yang diproses dengan pinang dan binding agent memperlihatkan bahwa pinang lebih banyak menempel pada pemukaan kain. Hal tersebut disebabkan karena fungsi penggunaan binder adalah memberikan ikatan kimia pinang dengan kain (Gambar 2b,2c, dan 2d).

\section{Spektrum FTIR}

Gambar 3 menunjukkan spektrum FTIR pada kain yang diproses dan tanpa diproses dengan ekstrak pinang serta kain yang diproses dengan pinang tanpa dan dengan menggunakan binding agent. Dari gambar tersebut dapat dilihat bahwa terdapat kesamaan puncak serapan antara kain kapas dengan oleoresin. Spektrum pada kain kapas dan oleoresin pada pinang menunjukkan beberapa puncak diantaranya yaitu pada panjang gelombang 3400, 2900, 1600, 1500, 1400, 1300 dan $1000 \mathrm{~cm}-$ 1 , dimana terdapat gugus $\mathrm{OH}, \mathrm{CH}, \mathrm{C}=\mathrm{C}, \mathrm{C}=\mathrm{O}$, $\mathrm{CH}_{2}, \mathrm{C}-\mathrm{O}$. 


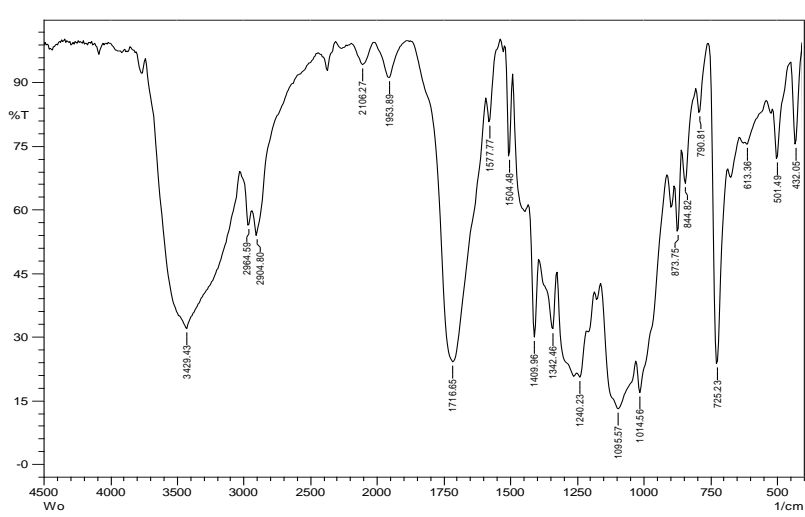

(a)

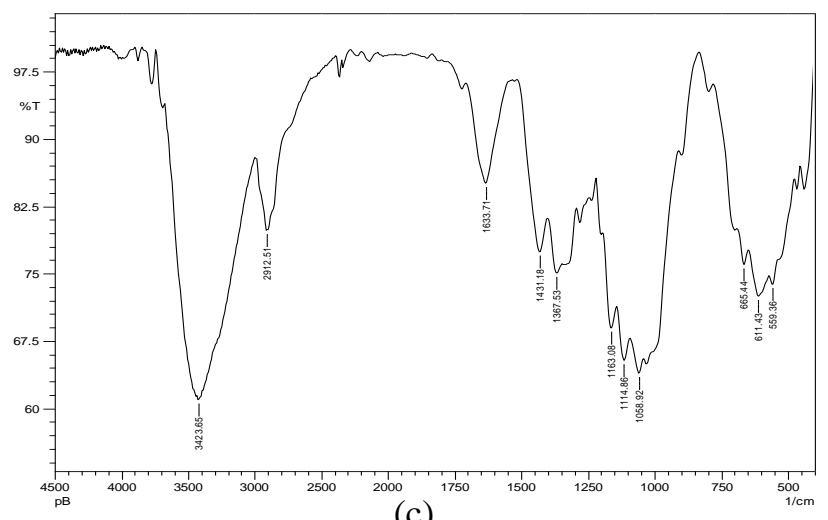

(c)

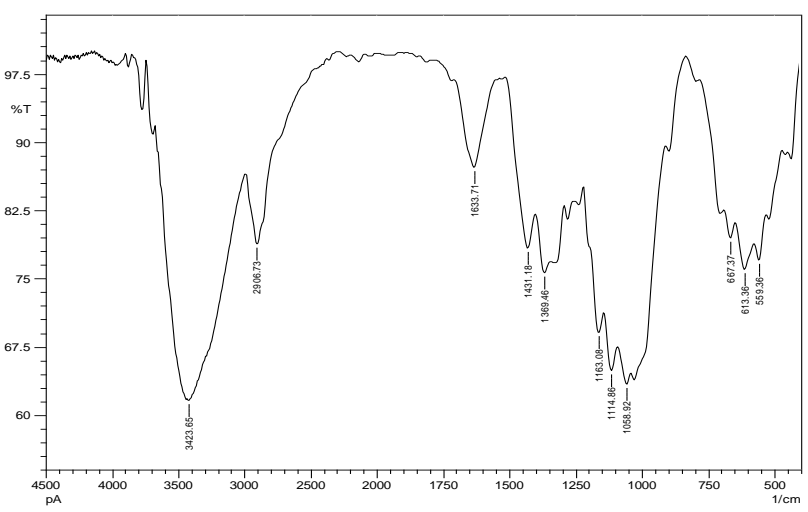

(b)

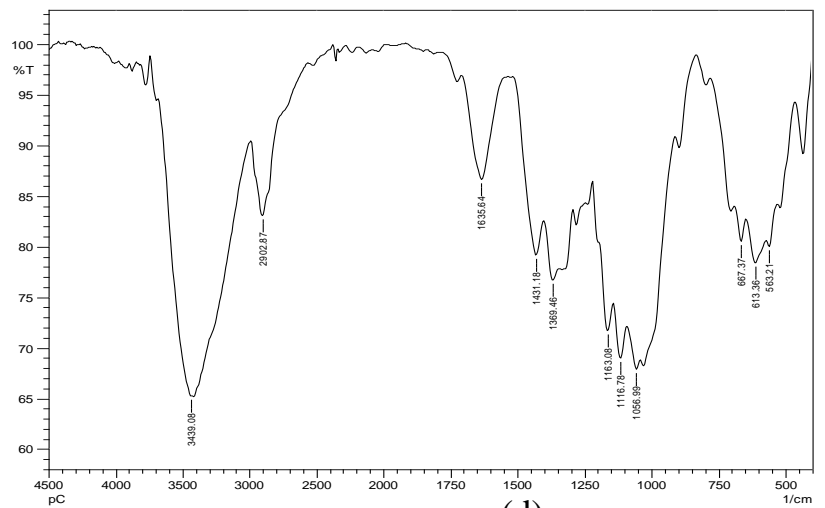

(d)

Gambar 3. Spektrum FTIR kain kapas (a) tidak diproses dengan pinang; (b) kain kapas diproses dengan pinang + PVA; (c) kain kapas diproses dengan pinang + binder 722; (d) kain kapas diproses dengan pinang + poliuretan

\section{KESIMPULAN} bahwa:

Dari hasil penelitian ini dapat disimpulkan

1. Pinang dapat digunakan sebagai bahan antibakteri alami karena dapat dplikasikan pada kain kapas dengan metode pad-drycure.

2. Pinang dapat digunakan sebagai zat antibakteri. Hal ini ditunjukkan pada hasil uji antibakteri yang mengalami kenaikan dengan bertambahnya konsentrasi pinang dalam kain, baik untuk bakteri E. Coli maupun S. Aureus.

3. Kain kapas yang ditambahkan pinang dan binder 722 membentuk ikatan kimia yang paling baik, hal tersebut ditunjukkan pada hasil pencucian sebanyak 9 kali yang tidak mengalami penurunan yang signifikan sebagai zat antibakteri yaitu $E$. coli dari $99,5 \%$ menjadi $97,4 \%$ dan $S$. aureus dari $95,1 \%$ menjadi $92,2 \%$.

\section{PUSTAKA}

1. Ganiswarna. G Sulistia. Farmakologi dan Terapi edisi 4 dan 5. Bagian Farmakologi Fakultas Kedokteran UI. Jakarta (1999)
2. Pelczar, Dasar-Dasar Mikrobiologi 2. Jakarta: Universitas Indonesia Press. (1988).

3. Rathinamoorthy R, Udayakumar S \& Thilagavaty G, Int J Pharma Life Sci, 2 11-47. (2011)

4. Loper JE, Henkels MD, Roberts RG, Grove GG, Willett MJ and Smith TJ. Evaluation of streptomycin, oxatetracycline, and copper resistance of Erwinia amylovora isolated from pear orchards in Washington State. Plant Dis. 75: 287-290 (1999).

5. Davis J.. Inactivation of antibiotics and the dissemination of resistance gene. Science. 264:375-382. (1994)

6. Service RF. Antibiotics that resist resistance. Science. 270:724-727 (1995).

7. Chiu C.H., Wu T.L., Su L.H., Chu C., Chia J.H., Kuo A.J., Chien M.S. and Lin T.Y. The emergence in Taiwan of fluoroquinolone resistance in Salmonella enterica serotype Choleraesuis. N Engl J Med. 346: 413-419 (2002). 
8. Boonmar S, Bangtrakulnonth A, Pornruangwong S, Samosornsuk S, Kaneko K and Ogawa M. Significant increase in antibiotic resistance of Salmonella isolates from human beings and chicken meat in Thailand. Vet Microbiol. 62: 73-80 (1998).

9. Davis M.A., Hancock D.D., Besser T.E., Rice D.H., Gay J.M., Gay C., Gearhart L. and DiGiacomo R. Changes in antimicrobial resistance among Salmonella enterica serovar Typhimurium isolates from humans and cattle in the Northwestern United States, 1982-1997. Emerg Infect Dis 5: 802-806 (1999).

10. Dwidjoseputro, Dasar-Dasar Mikrobiologi. Jakarta: Djambatan (2003).

11. IARC, Betel-quid and areca-nut chewing and some areca-nut derived nitrosamines. IARC Monogr. Eval. Carcinog. Risks Hum. 85, 1334 (2004).

12. Cordell GA. Bioderversity and drug discovery a symbiotic relationship. Phytochem. 55: 463480 (2000).
13. Harbone, J.B. Metode Fitokimia. Edisi ke-2. ITB. Bandung (1996).

14. Nonaka, G., 1989, Isolation and structure elucidation of tannins, Pure \& Appl. Chem, 61 (3): 357-360 (1989).

15. Fine, A.M., 2000, Oligomeric Proanthocyanidin Complexes: History, Structure, and Phytopharmaceutical Applications, Altern Med Rev, 5(2):144-151 (2000).

16. Hernandez, N. E, Tereschuk, M. L., Abdala, L. R. Antimicrobial activity of flavonoids in medicinal plants from Tafi' del Valle (Tucuma'n, Argentina). Journal of ethnofarmacology 73 (317-322) (2000)

17. Jussi-Pekka Rauha, J. P, et. al. Antimicrobial effects of Finnish plant extracts containing flavonoids and other phenolic compounds. International Journal of Microbiology 56 (3-12) (2000) 
Arena Tekstil Vol. 34 No. 2, 2019 : 85-92 